\title{
Counselling for Security, Creativity and Learning in Early Childhood Education
}

\author{
Domike Grace Chikadibia* and Undie, Ushinyin Josephine $^{* *}$ \\ ${ }^{*}$ Department of Curriculum and Teaching, Faculty of Education, University of Calabar, Calabar, Nigeria \\ ${ }^{* *}$ Department of Early Childhood Care Education, Cross River State College of Education, Akamkpa- Nigeria
}

\begin{abstract}
The paper examines counselling for security, creativity and learning in early childhood education. Primary data was collected through validated instrument of questionnaire administration. Stratified random sampling was used for sample selection to elicit information from 285 respondents who were counsellors from six Local Governments Areas in Akwa Ibom State. Logistic regression was used for data analysis. The result revealed that counselling for security had a significant effect on learning in early childhood education. Also, creativity has a significant effect on learning in early childhood education. The paper suggests that counsellors should integrate developmental and preventive strategies that are comprehensive in counselling children to act in a proactive and goal oriented manner.
\end{abstract}

Keywords: Early Childhood Education, Counselling

DOI: $10.7176 / \mathrm{JEP} / 10-11-13$

Publication date: April $30^{\text {th }} 2019$

\section{Introduction}

Education is the transmission of what is worthwhile to those who become committed and a process essential to the achievements of personal goals and individual aspirations. Education describes the total process of human learning by which learning is imparted and skills developed. As a process, education involves the development of the physical, mental and spiritual potentialities of a child, process of moulding the whole child to be useful to himself and to his society. Learning is assumed to occur if a difference exists in the child's behaviour before and after his encounter with the environment. The behaviour could be overt, like when the child engages in observable physical activities like talking in a new language, walking in a new style. The behaviour could also be covert (existing only in the mind) like when the child has a mental picture of the map of Nigeria, or when he can mentally glean through a new mathematical formular taught in class (Nnachi, 2007).

Learning in early childhood is when a new behaviour manifests by an individual; the presumption is that learning has taken place. For instance, a child who has acquired a new language after some practice is said to have learned. Learning amounts to the gaining of knowledge or skill through practice. Through practice, a child learns new ways of life or new languages (Iheanacho, 2002). In the learning situation, creativity involves the ability to evolve original and uncommon applicable methods to problem solving. In school environment, creativity is an important factor in the child's ability to learn and adjust. In problem solving situation, the child needs creativity to be effective.

Creativity is a process that involves the bringing to birth of something new. In the school setting, a child finds himself participating in all arrays of activities - both academic and co-curricular activities. In the process, they are looked upon to reason and think critically, build concepts and see relationships among objects and events. Even as children, counselling helps them understand themselves better and the roles expected of them by school, their parents and the society. This will go a long way in preventing instability or security. Smith (2002) added that, counselling is a process in which one person assists another person in a person-to-person or face to face encounter. It is obvious that counselling can in no small way produce solutions and help reduce the stress experienced by learners. This paper seeks to examine effect of counselling, creativity and learning in early childhood education. 


\section{THE NEED FOR COUNSELLING}

The need for counselling in Nigeria schools cannot be overemphasized. Counselling is meant for a child in distress. Counselling orientation is necessary to help prevent the mistake and frustrations that arise as a result of wrong educational foundations and so on. Throughout school, educational, vocational and personal-socio counselling are required to help learners cope with the experiences of schooling, counselling helps learners adjust and understand himself better, thereby avoiding some of the things that could necessarily cause maladjustment in school (Adegoke, 2003).

Counselling determines the learners competencies and needs based on developmental level using the three domains of educational or academic or learning, vocational or career development and or personal social needs. A counsellor has the duty of ensuring that these needs and other are brought to a minimal level of elimination to create and appropriate environment for the learner to learn. In addition to counselling and guiding children on educational, vocational and personal social needs, the counsellor carries out orientation of learners, act as liaison between learners and significant others like pupils' records (Dinkmeyer, 1985).

\section{COUNSELLING SERVICE}

The counsellor uses the counselling service which is a personalized dialogue, interview between a counselee or group of individuals or counselees experiencing a problem and the counsellor who tries to render help or assistance. It is the heart of guidance since it provides interaction (Alao \& Adeniyi, 2009).

\section{APPRAISAL SERVICE}

The counsellor uses this service to collect descriptive and objective information on individuals or groups of individuals that will facilitate decision making. Appraisal instruments include tests such as aptitude, achievement, intelligence as well as non-test materials such as rating scales, observations, interview and anecdotal records.

\section{EDUCATIONAL COUNSELLING}

Educational counselling begins from the first day in school and runs from the pre-primary, primary, junior secondary, senior secondary through the tertiary institutions. In educational sector, the counsellor starts with giving orientation to the child. The child will be taught how to be attentive during classes (Braide, 2005). For instance, in counselling a case of study habit, the counsellor will ask the child to look at all sides of the problem, assist the child to assess his potentials through test.

\section{VOCATIONAL COUNSELLING}

Vocational counselling takes place in schools where the child makes a life changing decision about what he wants to do after school. In this case, the counsellor will ask the learner to ask himself about his personality; make a list of the hobbies, games, take a personality test. The counsellor will encourage him to keep updating the list, and make a decision that will provide a sense of accomplishment and satisfaction.

\section{PERSONAL COUNSELLING}

According to Ekpekin and Ekanem (2005), warm acceptance, genuineness, listening, information acquisition and follow-up are the most essential techniques needed. The counsellor can give a little warm welcome smile of you "How are you?" this may give the learner confidence that will motivate him to speak. The counsellor suggests activities such as going out for social activities together, engaging in sports/games.

\section{STRATEGIC APPLICATION OF COUNSELLING}

A counsellor adopts strategic application of counselling in school. He develops lessons in the classroom within a stipulated time frame on the school time table. A counsellor offers cost effective service to all children in the classroom setting, it allows counsellors to aid learners progress through various developmental stages as they grow and mature. In school setting, a counsellor teaches, assists and coordinates teachers in such a way that it produces a holistic build-up that will be meaningful to both the individual learner and the society (Onah, 2010). 


\section{CREATIVITY}

According to Isangedighi (2007), creativity involves the ability to evolve original and uncommon applicable methods to problem solving. As a process, creativity is the ability to combine ideas, things, techniques and approaches in a new situation. Creativity is a process that involves the bringing to birth of something new. In the school setting, the learner finds himself participating in all arrays of activities — both academic and cocurricular activities. In school, the child needs creativity to be effective, it is manifested as unique communication, creative writing and artistic experience in the form of drawing. A child has the ability to combine ideas, things, techniques and approaches in a new situation (Isangedighi, 2011).

\section{LEARNING IN EARLY CHILDHOOD EDUCATION}

Education in the general sense covers the whole life of an individual from birth till death or from cradle to grave showing that education is as old as man on earth. Education is the key to development in any nation. Learning as a change in behaviour or performance, which is a result of experience and practice, and which makes an individual face later situation differently. It must quickly be pointed out that the change in behaviour or performance should lead to improvement if learning has taken place, especially in school settings (Denga, 2002). A child who experiences that mathematics is difficult and changes his attitude or behaviour towards it by simply going into hiding whenever mathematics is being taught. If a child is exposed to cheating behaviour and becomes an expert at cheating, he has certainly learnt, but this change in behaviour, from the societal and legal point of view, does not constitute improvement. If a child is taught how to spell words in English and how to solve some problems in mathematics and he does these better than what he knew at the entry behaviour, then learning has taken place. This better or improved performance has resulted from experience and practice and can be considered a positive change in behaviour as far as learning in childhood education is concerned (Robert, 2002).

\section{PRINCIPLES OF LEARNING}

These are simply guides to learning which every teacher ought to know. Any successful learning must take these essential principles into consideration.

1. Readiness and individual difference

A child must be ready for the learning material they are to learn. Developmental levels of children are critical to ensure that the material being taught is not too difficult. Similarly, teachers should recognize individual differences among children. These differences may be physical, intellectual, social and cultural.

\section{Motivation to learn facilitates learning}

Perhaps, the key to every teachers' success in his profession resides in motivating a child. Motivation refers to forces that energize and direct behaviour. Children's interests, needs and motives are critical in learning. A child learns very effectively if he sees a need that his learning will meet incentives, rewards and other forms of reinforcements motivate children.

3. Learning becomes more rapid and meaningful: If the new learning is linked with the old, it is a sound learning principle to start from the simple to the complex and from the old to the new.

4. Learning should be to children's interests, goals and needs and should be tailored to suit their experiences, age and capacities.

5. Learning must be tailored to suit children of all kinds of abilities the slow learners, the normal and the gifted learners.

6. Children learn better by active participation in the learning process. Teachers need therefore, to provide adequate purposeful child activity in their daily teaching. Teachers instruct group or classes, but individual children learn according to their ability and rates of assimilation.

\section{MATERIAL AND METHOD}

This research is designed to employ the use of survey method to elicit information on counselling for security, creativity and learning in early childhood education. The instrument used to collect data for this research was through a pretested designed questionnaire. The questions in the questionnaire were centered on 
counselling for security, creativity and learning in early childhood education. The population of study was counsellors of primary schools in Akwa Ibom State where 285 samples were selected through the use of stratified random sample across the six Local Government Areas in Akwa Ibom State.

\section{LOGISTIC REGRESSION}

Logistic regression is a flexible method for modeling and testing the relationship between one or more quantitative and categorical explanatory (independent) variables and one binary (i.e. two levels) categorical outcome. Logistic regression is used to estimate the existed relationship between the independent variables (counselling for security, creativity and the dependent variable (learning) as a measure of childhood education.

Similar method was employed by Ajao, Obafemi and Lawal (2011). The two levels of the outcome can represent anything, such as success and failure. It is applied that code 1 represents success and code 0 represents failure. It is stated thus modeling the success probability is a function of the explanatory variable. Then $0 / 1$ coding makes it true that the mean of y represents the observed function of success for that group. Logistic regression shows that, there is usually an intercept parameter ( ) plus one parameter for school explanatory variable (through) and these are used in the linear combination form ( ).

In logistic regression, a complex formula is needed to change back from the logistic equation to the OLS-type equation. The formulas are stated in terms of the probability that $y=1$, which is referred to a $p$. the probability that $\mathrm{y}$ is 0 is $1-\mathrm{p}()$. $\mathrm{P}$ is computed if the regression equation is known, then to compute expected probability is $\mathrm{y}-1$ for a given value of $\mathrm{x}$

\section{DISCUSSION OF RESULTS}

Based on the binary logistic regression analysis, the result revealed that there is a significant and positive relationship between counselling for security and learning in early childhood education Odd Ratio (OR) $=2.05, \mathrm{p}=0.09$ i.e. counselling for security is 2.05 times more likely to be involved in counselling. There is a significant and positive relationship between creativity and learning in early childhood education $(\mathrm{OR}=0.07, \mathrm{p}$ $=0.001$ ), i.e. counsellors who are creative are equally to be involved in childhood education.

\section{CONCLUSION/RECOMMENDATION}

From the results, it can be concluded that counselling for security has a significant effect on learning in early childhood education. Creativity has a significant effect on learning in early childhood education. Counselling determines the learner's competencies and needs based on developmental level; it guides children on educational, vocational and personal social needs. It is recommended that counsellors should integrate developmental and preventive strategies that are comprehensive on counselling the child to act in a proactive and goal oriented manner

\section{REFERENCES}

Adegoke, A. A. (2003). Counselling curriculum for schools in Nigeria. A publication of the Counselling Association of Nigeria (CASSON). Ilorin: Goshen Print Media Limited.

Ajao, I. O., Obafemi, O. S. \& Lawal, A. S. (2011). Influence of some risk factors on maternal mode of delivery: Binary logistic regression approach. International Journal of Physical Science, 6(1), 10.

Braide, E. I. (2005). Chairmans remarks. A key note address delivered at the Annual National Conference of the Counselling Association of Nigeria (CASSON) on 16th August, at the University of Calabar, Calabar.

Denga, D. I. (2002). Educational and social psychology: For schools and other social organizaitons. Calabar: Rapid Educational Publishers Ltd.

Dinkmeyer, D. (1985). Child development, the emerging self. Englewood Cliffs. New Jersey: Prentice-Hall.

Ekpekin, E. \& Ekanem, S. A. (2005). Re-orienting Nigerians towards realities of world of work: The counsellors perspective. The Forum, a Publication of the World Council of Curriculum, 5(1\& 2). 
Iheanacho, R. A. E. (2002). Psychology of learning. Owerri: G. O. C. International Publishers.

Isangedighi, A. J. (2007). Child psychology: Development and education. Calabar: Eti-Nwa Associates.

Isangedighi, A. J. (2011). Essentials of learning. Calabar: Eti-Nwa Associates.

Nnachi, R. O. (2007). Advanced psychology of learning and scientific enquires. Enugu: John Jacob Classic Publishers.

Onah, O. A. (2010). The counselling implication of examination malpractice. Nigeria Journal of Science, Teach and Environmental Education, 3(1).

Roberts, N. (2002). An exploration of underachievers in the classroom. A Peer Reviewed Journal, 7(3), 1-15.

Smith, D. (2002). Gifted achievers and underachievers, a comparison of patterns in school files. Journal of Counselling and Development, 74, 399 - 407 